BIOKEMISTRI 17(2):101-106 (Dec 2005)

Available online at http://www.bioline.org. br/bk.

Abstracted online at www.ajol.info/journals/biokem
Rn international journal published by the

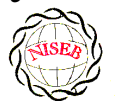

OVgerian \&ociety for Eิxperimental Siology

Printed in Nigeria

\title{
Effects of the cimetidine on the biliary excretion of rosebengal in rats
}

\author{
Albert. C. ACHUDUME \\ Institute of Ecology and Environmental Studies, Obafemi Awolowo University, Ile-Ife, Nigeria
}

Received 20 May 2002

MS/No BKM/2002/014, ( 2005 Nigerian Society for Experimental Biology. All rights reserved.

\begin{abstract}
Effect of the cimetidine on the biliary excretion of Rosebengal (RBG) was determined in rat after treatment with two different doses of cimetidine $80 \mathrm{mg} / \mathrm{kg}$ and $/$ or $10 \mathrm{mg} / \mathrm{kg}$ in aqueous solution administered intraperitoneally. Rosebengal $(4 \mathrm{mg} / \mathrm{kg})$ was administered i.p. After treatment the excretion pattern of the effect of cimetidine on bile flow, plasma and liver were studied. The study showed that cimetidine at $80 \mathrm{mg} / \mathrm{kg}$ increased the plasma concentration of $\mathrm{RBG}$ excreted up to $45 \mathrm{~min}$ after administration while bile flow continued to increase even after 120 mini of treatment. At both concentrations of cimetidine there was a tendency in the direction of an increase in bile flew, plasma, liver weight and RBG liver concentrations, while there was decrease in RBG biliary excretion and RBG bile concentration. The excretion of RBG from hepatic cells in bile suggests that cimetidine has negative effect on the liver cells.
\end{abstract}

Key words: Cimetidine, biliary excretion, bile flow, rosebengal

*Author to whom all correspondence should be addressed.

E-mail: aachudum@yahoo.com Tel: +234-36-231094 


\section{INTRODUCTION}

Metabolism of environmental contaminants occurs in multiple organs and the site of metabolism is an important determinant of a compound's toxicity. Cimetidine is a drug used in the treatment of peptic ulcer and as a prophylactic in gastric hyperactivity in $\operatorname{man}^{1,2}$. The metabolism of cimetidine occurs by sulphoxidation, which can be induced by phenobarbitone ${ }^{3}$. Drug interactions with cimetidine found to be associated with a number of adverse reactions have been reported in patients undergoing therapy with cimetidine coadministered with other medications ${ }^{4}$. Cimetidine is an $\mathrm{H}_{2}$ Receptor affects cytochrome P.450 of the microsomes of hepatocytes ${ }^{5,6}$.

Studies on the effect of cimetidine after a single dose showed a clear relationship between blood concentration and extent of inhibition of basal gastric $\operatorname{acid}^{7}$. When cimetidine was co-administered with other drugs clinically significant drug-drug interactions were observed and reported ${ }^{8,9}$. The excretion rate of cimetidine may invariably determine the duration of action. In view of the occurrence of drug-related adverse reactions and their possible relationship with differential metabolism and accumulation of derivatives, the present study is designed to investigate the effect of cimetidine on hepatobiliary function in rat. Biliary excretion of rosebengal, a cholephilic organic anion was used as an index for liver functions. The dye was chosen because it is completely and rapidly excreted into the bile by an active process $^{10}$ and to study its effect on liver function.

\section{MATERIAL AND METHODS}

Cimetidine [N'-cyano-N-methyl N'[2]- (5-methylimidazal 4-yl) methyl-thio-ethylguanidine)] was obtained from pharmacology Department, faculty of pharmacy, Obafemi Awolowo University, Ile-Ife. Rosebengal (RBG) was obtained from British Drug House.

\section{Animals and Treatment}

Twenty male Wister albino rats weighing between 200-300g were used throughout. Two doses of cimetidine $(80 \mathrm{mg} / \mathrm{kg}$ and or $10 \mathrm{mg} / \mathrm{kg}$ ) in aqueous solution were administered i.p. The control received an equivalent of the aqueous solution. Following the administration of cimetidine, freshly prepared RBG $4 \mathrm{mg} / \mathrm{kg}$ in $0.9 \%$ saline solution was administered into the femoral vein (Hynson, Westcott and Dunning Inc.). The saline solutions were made up to deliver the proper dosage in a final volume of $8 \mathrm{ml} / \mathrm{kg}$.

\section{Biliary Flow}

The rats were anesthetized with Phenobarbital sodium $\quad(50 \mathrm{mg} / \mathrm{kg} \quad$ i.p) supplemental doses being administered as needed. The common bile duct was surgically exposed by an abdominal incision $(25 \mathrm{~mm})$ and cannulated with a sterile 25 gauge $(5 \times 8)$ hypodermic needle shaft attached to $20 \mathrm{~mm}$ pieces of PE-10 tubing. The rectal temperature of the anesthetized rat was maintained at $37^{\circ} \mathrm{C}$ with a heat lamp to prevent hypothermic alteration in biliary flow ${ }^{11}$. Four bile samples of $15 \mathrm{~min}$ duration each, were collected and the volume measured by weighing ${ }^{12}$. At the end of the experiment, blood was withdrawn by cardiac puncture and the liver was removed, blotted free of excess blood and weighed. The RBG concentrations in bile, plasma and liver were determined by measuring its absorption with Cecil spectrophotometer (CE 37.3) at $545 \mathrm{~nm}$. The change in RBG concentrations ratio of plasma-to-liver, bile-to-plasma and bile-to-liver were calculated ${ }^{13}$. The results were expressed as means \pm SE. the significance was assessed by student's t-test.

\section{RESULTS}

Table 1 shows the effect of cimetidine on volume and the rate of bile flow. The concentrations of RBG in the volume of bile per $100 \mathrm{~g}$ of animal were observed to correlate with the rate of which cimetidine influenced bile flow.

A single intraperitoneal injection of cimetidine in aqueous solution given to Wistar rats resulted in marked increase $(\mathrm{P}<0.05)$ in RBG plasma concentration with a maximal response at $45 \mathrm{~min}$ (Fig. 1a). However the bile flow continued to increase through the 120min (Fig 1b). 
(a) RBG Plasma Concentration

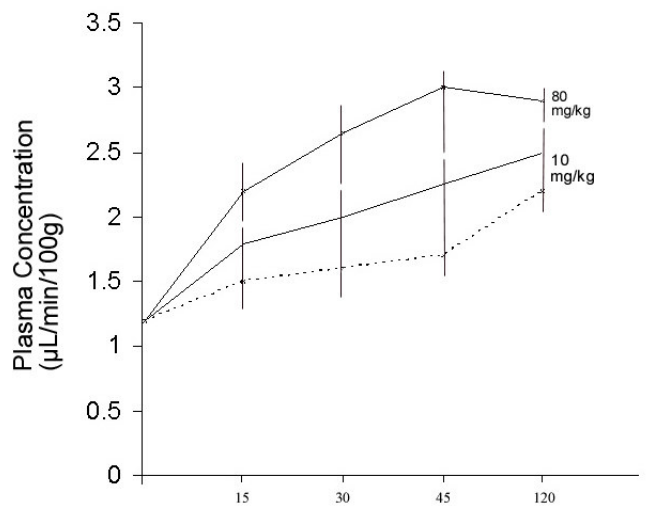

(b) Bile Flow

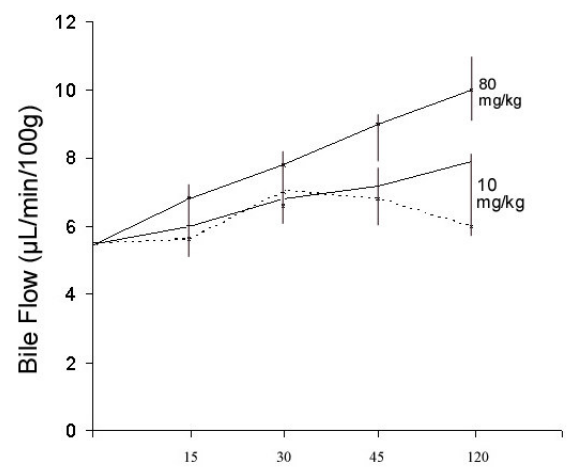

Fig 1. EFFECT OF CIMETIDINE ON PLASMA CONCENTRATION OF RBG

Table 1:Effect of cimetidine on bile flow

\begin{tabular}{|l|l|c|l|c|}
\hline $\begin{array}{l}\text { Time } \\
(\mathrm{min})\end{array}$ & \multicolumn{2}{|l|}{$\begin{array}{l}\text { Volume of bile } \\
\text { collected per } \\
100 \mathrm{~g} \text { of } \\
\text { animals' }(\mathrm{ml})\end{array}$} & \multicolumn{2}{l|}{$\begin{array}{l}\text { Rate of bile } \\
\text { flow ml/Min }\end{array}$} \\
\hline & Test & Control & Test & Control \\
\hline 0 & 0.082 & 0.133 & 5.67 & 5.9 \\
& \pm 0.05 & \pm 0.03 & $\times 10^{-3}$ & $\times 10^{-3}$ \\
\hline 15 & 0.095 & 0.118 & 6.33 & 6.0 \\
& \pm 0.12 & \pm 0.05 & $\times 10^{-3}$ & $\times 10^{-3}$ \\
\hline 30 & 0.119 & 0.110 & 7.93 & 6.2 \\
& \pm 0.03 & \pm 0.04 & $\times 10^{-3}$ & $\times 10^{-3}$ \\
\hline 45 & 0.110 & 0.101 & 7.33 & 6.0 \\
& \pm 0.10 & \pm 0.05 & $\times 10^{-3}$ & $\times 10^{-3}$ \\
\hline 120 & 0.105 & 0.095 & 7.00 & 6.3 \\
& \pm 0.11 & \pm 0.01 & $\times 10^{-3}$ & $\times 10^{-3}$ \\
\hline
\end{tabular}

Temporal accumulation of hepatic bile and the rate of flow after cimetidine administration.

The mean $\pm S$. E of the volume of the bile of five animals (a) RBG Biliary Excretion

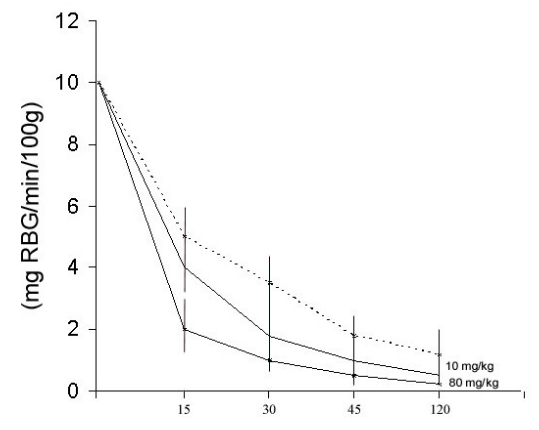

(b) RBG Bile Concentration

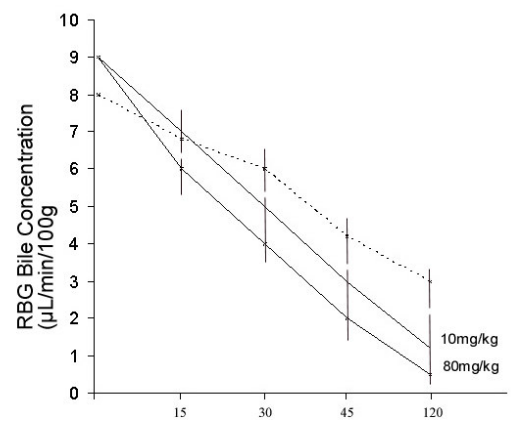

Fig 2. EFFECT OF CIMETIDINE ON BILIARY EXCRETION
OF RBG

(a) Liver Weight

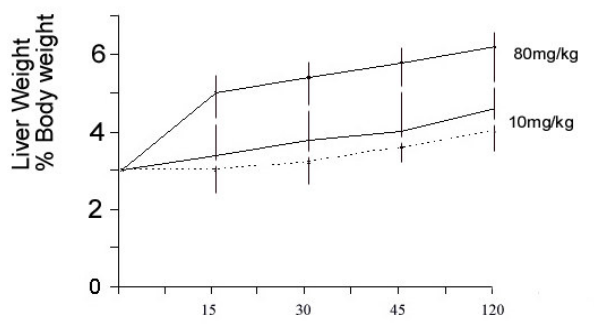

(b) RBG Liver Concentration

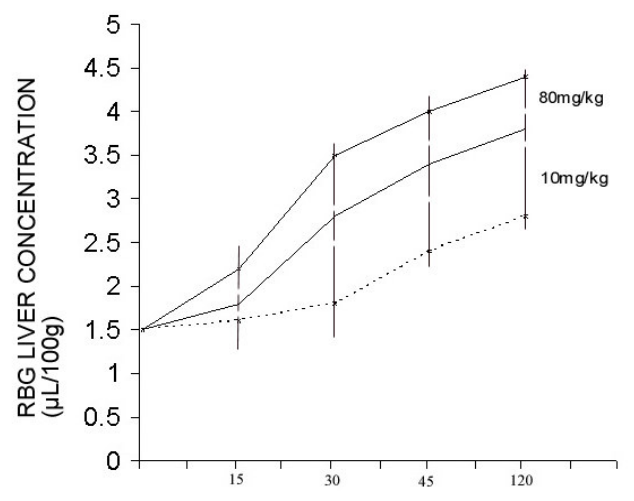

Fig 3. EFFECT OF CIMETIDINE ON LIVER WEIGHT AFTER TREATMENT 

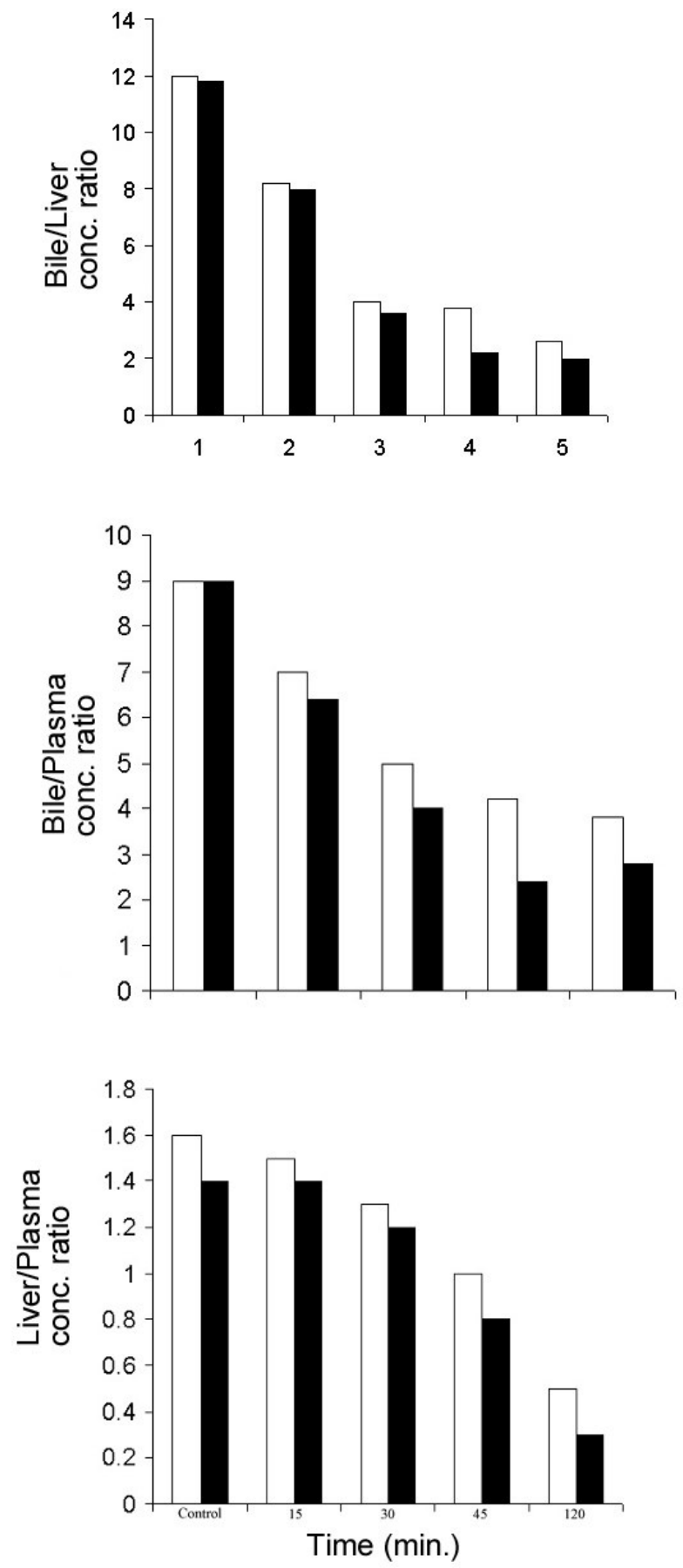

Fig 4. Change in RBG concrete ratio after vivetidine treatment

The rats receiving $80 \mathrm{mg} / \mathrm{kg}$ cimetidine had higher flow rates than those receiving $10 \mathrm{mg} / \mathrm{kg}$ cimetidine. However, treatment of the animals with the same concentrations of cimetidine decreased the RBG biliary excretion (Fig. 2a) and RBG bile concentration (Fig. 2b).
The decrease continued throughout the 120min experimental time limit. Cimetidine caused marked increase in liver weight through not significant as shown in Figure 3a. The increase concentration in RBG in the liver as expressed in microlitre per $100 \mathrm{~g}$ body weight was also dose related since the higher dose caused a greater weight increase.

Bile-to-liver (a) bile-to-plasma (b) Liver-to-plasma (c) concentration ratios of RBG were separately calculated and compared as shown in Figure 4. The change in RBG concentration ratios after cimetidine treatment decreased gradually and continued to decrease after 120min. The liver accumulated less of RBG after cimetidine treatment. Liver to plasma RBG concentration ratios decreased in animals treated with $80 \mathrm{mg} / \mathrm{kg}$ and very rapidly after $30 \mathrm{~min}$ for those treated with $10 \mathrm{mg} / \mathrm{kg}$ (Fig 4c). The control animals are observed to retain RBC specially the $80 \mathrm{mg} / \mathrm{kg}$ dose gave a much greater retention than $10 \mathrm{mg} / \mathrm{kg}$. All the ratios were decreased at $120 \mathrm{~min}$.

\section{DISCUSSION}

Identifying the existence of potentially interfering substance that is clinically useful either as prophylaxis or for routine differential diagnosis of hepatobilary diseases is obviously to reduce the toxic effect of the secretive substances. An important parameter in determining the rates of such secretion of a compound into the bile is the biliary flow ${ }^{14}$. The production of bile is also a function of hepatic cells ${ }^{15}$. Most compounds that will affect biliary flow will therefore affect the liver function. The effect of cimetidine on volume and rate of bile flow in Table 1 shows that cimetidine treatment increases bile flow, which may be due to the action of metabolizing enzyme inducers because phenobabitone have equally been observed to increase biliary flow by a number of microsomal enzyme inducers ${ }^{11}$.

Figures $1 \mathrm{a}$ and $\mathrm{b}$ show that cimetidine increases both the plasma concentration of RBG excreted and bile level. The observed increase in biliary flow indicates that treatment with normal dose of cimetidine for $30 \mathrm{~min}$ alters the response and suggests that it is likely to affect the reabsorption of fluid along the bile duct. 
Though, the concentration of RBG in bile of cimetidine treated rat was lower than that of the control $30 \mathrm{~min}$ after RBG administration, the RBG concentration continues to decrease for up to $120 \mathrm{~min}$ (Fig. 2a and b). The RBG concentration in the liver are however higher than the controls and are observed to remain high at 120 min after administration (Fig. 2a and b). These responses show that the administered drug has a negative effect on the function of the liver as regard the excretion of RBG by causing retention of RBG in liver cells.

Despite a single dose and the time depended nature of the study, significant correlation are observed when rats were treated with tetrachloride - dibenzo-p-dioxin (TCDD) on the biliary excretion of Indocynanine Green (ICG) ${ }^{16,17}$. Thus the use of RBG may be equally favoured in liver dysfunction and could be a good substitute for ICG. Since cimetidine enhances the RBG update but inhibits its excretion by the hepatic cells, it is possible that this observation perhaps may have led to the decrease in total RBG excreted and slights increases in the liver weight and RBG liver concentration (Fig. 3). By calculation the ratios of bile-to-liver, bile-to-plasma and liver-toplasma were compared. For unknown reasons, the ratio decreases even with higher doses (Fig. 4).

In conclusion, the results suggest that cimetidine increases the RBG plasma concentration and simultaneously decreases biliary excretion of the same compound. The study does not address mechanism responsible for this change.

\section{REFERENCES}

1. Costa, M., Antonio, M. A. and Brito, A. R. M. (1997) Effects of prolonged administration of Musa Paradisiaca L. (Ibadan) an antiulcerogenic substance in rats. Phytothera Res. 11:28-31.

2. Adams, W. J., Lawson, J. A. and Morris, D. L. (1994) Cimetidine inhibits in vivo growth of human colon cancer and reverses histamine stimulated in vitro and in vivo growth. Gut 35:1632-1636.
3. Dixon P. A. F. and Udeagba, A. U. (1986) The effect of some hepatotoxins on the sulfoxidation of cimetidine in rat. Comp. Biochem. Physio 830:385-386.

4. Fletcher, C. V., Henry, W. K., Noormohamed, S. E., Rhame, F. S. and Balfour, H. H. (1995) The effect of cimetidine and ranitidine administration with zidovudine. Pharmacotheraphy 15:701-708.

5. Rendiae, S. (1999) Drug interactions of H-2 receptor antagonists involving cytochrome P. 450 (CYPs) enzymes: from the laboratory to the clinic. Croatian Med J. 40:357-87.

6. Chang T., Levine, M. and Bellward, G. D. (1992) Selective inhibition of rat hepatic microsomal cytochrome P.-450. 1. Effect of the in vivo administration of cimetidine. $J$. Pharmacol Exp. Ther 260: 1441-1449.

7. Henn, R. M., Isenberg, J. I., Maxwell, V. and Strurdevant, A. L. (1975) Inhibition of gastric acid secretion by cimetidine in patients with duodenal ulcer. $N$ Engl J Med 293:371-374.

8. Faux, S. P. and Combes, R. D, (1994) Interaction of cimetidine with oxidized and prereduced microsomal cytochrome P.450. Drug Metab. Dispos. 22:180-182

9. Forgue, S. T., Reece, P. A., Sedman, A. J. and deVries, T. M. (1996) Inhibition of tacrine oral clearance by cimetidine. Clin. Pharmacol. Therap. 59:444-449

10. Delprat, G. H. and Stowe, W. P. (1931) The rosebengal test for liver function $J$. Lab Clin Med. 16:923-925.

11. Klassen, C. D. (1969) Biliary flow after microsomal enzyme induction. J. Pharmacol Exptl. Therap 168:218-223.

12. Mckinney, T. D. and Hosford, M. A (1992) Organic cation transport by rat hepatocyte basolateral membrane vesicles. Am J. Physiol. 6:936-946.

13. Kobara, H., Uchida, N., Tsutsui, K., Kurokohchi, K., Fukuma, H., Ezaki, T. and Kuriyama, S. (2003) Abnormal bile flow in patients with achalasia. $J$. Gastroenterol. 38:327-331.

14. McPherson, F. J. and Lee, R. M. (1977) Biliary excretion and metabolism of $14 \mathrm{C}$ cimetidine following oral administration to 
male and female rats. Experientia 33:11391140

15. Fuchs, M. (2003) Bile acid regulation of hepatic physiology: III Regulation of bile acid synthesis: past progress and future challenges. Am J. Physiol Gastronitest Liver Physiol. 284:G551-557

16. Hwang, S. W. (1973) Effect of 2, 3, 7, 8 Tetrachloro-dibenzo-p-dioxin on the biliary excretion of indocyanine green in rat. Env. Health Pers. 10:227-230.

17. Nayan, R. and Sharma, R. K. (2002) Bile flow response to repetitive heat stress in rat. Indian J. Med Res 115:165-171. 